\title{
The Carbon Dioxide Emission as Indicator of the Geothermal Heat Flow: Review of Local and Regional Applications with a Special Focus on Italy
}

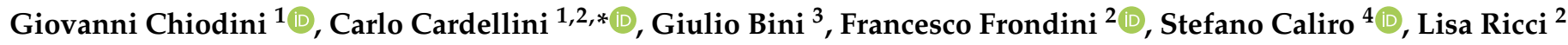 \\ and Barbara Lucidi ${ }^{2}$ \\ 1 Istituto Nazionale di Geofisica e Vulcanologia, Sezione di Bologna, Via D. Creti 12, 40128 Bologna, Italy; \\ giovanni.chiodini@ingv.it \\ 2 Dipartimento di Fisica e Geologia, Università di Perugia, Via Pascoli snc, 06123 Perugia, Italy; \\ francesco.frondini@unipg.it (F.F.); lisa.ricci@studenti.unipg.it (L.R.); babi.lucidi@gmail.com (B.L.) \\ 3 Institute of Geochemistry and Petrology, ETH Zürich, Clausiusstrasse 25, 8092 Zürich, Switzerland; \\ giulio.bini@erdw.ethz.ch \\ 4 Istituto Nazionale di Geofisica e Vulcanologia, Sezione di Napoli, Via Diocleziano 328, 80124 Napoli, Italy; \\ stefano.caliro@ingv.it \\ * Correspondence: carlo.cardellini@unipg.it; Tel.: +39-0755852698
}

Citation: Chiodini, G.; Cardellini, C.; Bini, G.; Frondini, F.; Caliro, S.; Ricci,

L.; Lucidi, B. The Carbon Dioxide Emission as Indicator of the Geothermal Heat Flow: Review of Local and Regional Applications with a Special Focus on Italy. Energies 2021 14, 6590. https://doi.org/10.3390/ en14206590

Academic Editors: Alessandro Sbrana, Paola Marianelli,

Roberto Gambini and

Jacek Majorowicz

Received: 22 July 2021

Accepted: 8 October 2021

Published: 13 October 2021

Publisher's Note: MDPI stays neutral with regard to jurisdictional claims in published maps and institutional affiliations.

Copyright: () 2021 by the authors. Licensee MDPI, Basel, Switzerland. This article is an open access article distributed under the terms and conditions of the Creative Commons Attribution (CC BY) license (https:// creativecommons.org/licenses/by/ $4.0 /)$.

\begin{abstract}
We review the methods based on the measurement of $\mathrm{CO}_{2}$ emissions for the computation of geothermal heat flow, both at a local (hydrothermal sites, a few $\mathrm{km}^{2}$ ) and regional scale (hundreds $\mathrm{km}^{2}$ ). At the local scale, we present and discuss the cases of the Latera caldera and Torre Alfina (Italy) geothermal systems. At Torre Alfina and Latera, the convection process sustains a $\mathrm{CO}_{2}$ emission of $\sim 1 \mathrm{~kg} \mathrm{~s}^{-1}$ and $\sim 4 \mathrm{~kg} \mathrm{~s}^{-1}$, and heat flows of $46 \mathrm{MW}$ and $130 \mathrm{MW}$, respectively. At the regional scale, we discuss the case of the central Apennine (Italy), where $\mathrm{CO}_{2}$ mass and enthalpy balances of regional aquifers highlights a wide and strong thermal anomaly in an area of low conductive heat flow. Notably, the $\mathrm{CO}_{2}$ / heat ratios computed for the central Apennines are very similar to those of the nearby geothermal systems of Latium and Tuscany, suggesting a common source of $\mathrm{CO}_{2}$-rich fluids ascribed to the Tyrrhenian mantle.
\end{abstract}

Keywords: carbon dioxide flux; heat flow; geothermal systems; central Apennines; convection

\section{Introduction}

Since the late seventies numerous studies have pointed to high carbon dioxide emissions in tectonically active regions frequently hosting geothermal systems [1-3]. Hightemperature geothermal systems form in active magmatic regions, where a large amount of heat is lost from the Earth's interior. The heat and mass transfer from a cooling magmatic intrusion to the groundwater drives fluid convection, boiling, and steam separation [4]. In the low-permeability and high-temperature ductile rocks hosting the intrusion, the heat transfer is dominated by conduction. Contrarily, convection dominates heat transfer in the permeable rocks of geothermal systems. The boiling of the convecting liquids produces a vapor-dominated phase with a significant amount of $\mathrm{CO}_{2}$, which flows towards the surface. Consequently, geothermal regions represent prevalent emitters of both geogenic $\mathrm{CO}_{2}$ and heat [5-9].

In these areas, $\mathrm{CO}_{2}$ is either emitted in the atmosphere through focused fumarolic vents, boiling pools, and areas of diffuse soil degassing [10-12], or dissolved in groundwater [13,14]. In the late 1990s, Kerrick et al. [5] developed a methodology based on convective heat flow measurements to estimate the relative flux of $\mathrm{CO}_{2}$ from geothermal systems. Subsequently, the development of techniques for measuring $\mathrm{CO}_{2}$ fluxes from volcanic and geothermal soil, such as the accumulation chamber [15] and eddy covariance [16], enabled the convective heat flow to be estimated by applying the reverse approach. 
The aim of this study was to synthesize in a unique document the principles and results of $\mathrm{CO}_{2}$-based techniques for the estimation of heat flow, referring to published and unpublished cases. In detail we will show how the measurement of soil $\mathrm{CO}_{2}$ degassing can be used to compute both the thermal emission from the hot soils of hydrothermal sites and the total heat associated with the convection of geothermal liquids. The published results obtained at Latera caldera (Italy) are presented and discussed together with those obtained from unpublished $\mathrm{CO}_{2}$ flux measurements performed at the Torre Alfina geothermal area (Italy). These cases show that $\mathrm{CO}_{2}$ flux measurements find useful applications in geothermal prospecting because they allow one to cheaply estimate the natural advectiveconvective heat flow.

Finally, we re-elaborated the published data of a regional investigation on the aquifers of the central Apennine (Italy) [17] computing, aquifer by aquifer, the total deeply derived $\mathrm{CO}_{2}$ emission and the geothermal heat flow from these hundreds of square kilometers wide areas. The results, supported by the $\mathrm{CO}_{2}$ concentrations and enthalpies of geothermal fluids of the region, indicate the presence of a geothermal source particularly rich in $\mathrm{CO}_{2}$ in central Italy.

\section{Geothermal Heat Flow from the Diffuse Emission of $\mathrm{CO}_{2}$}

According to [5], in geothermal systems heat and $\mathrm{CO}_{2}$ are transferred from depth to the surface through the convection of geothermal liquids (Figure 1). Based on this conceptual model, Kerrick et al. [5] used the heat flow measured at the surface to calculate the $\mathrm{CO}_{2}$ emission from the Taupo geothermal zone (New Zealand). Assuming the same conceptual model, in reverse the measured emission of $\mathrm{CO}_{2}$ can be used to compute the thermal energy of the upflowing geothermal fluids.

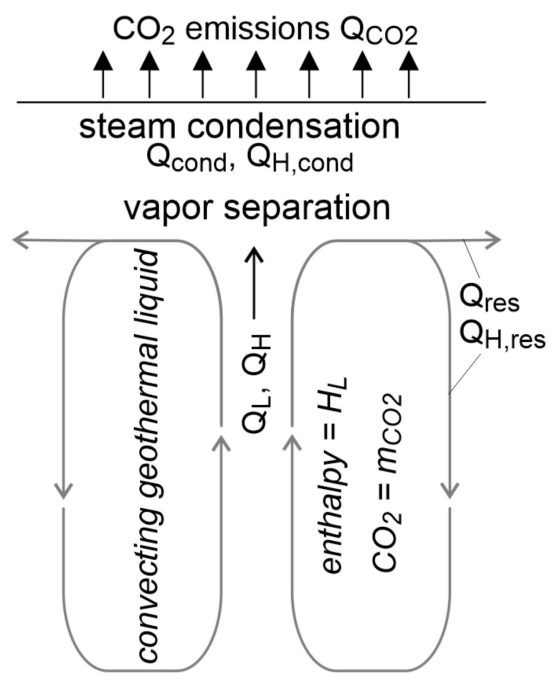

Figure 1. Sketch of the conceptual model of $\mathrm{CO}_{2}$ and heat transfer in a geothermal system.

Considering that the $\mathrm{CO}_{2}$ flow towards the surface $\left(\mathrm{Q}_{\mathrm{CO} 2}\right.$ in $\left.\mathrm{kg} \mathrm{s}^{-1}\right)$ is sustained by the depressurization and boiling of the geothermal liquid during its upflow (Figure 1), the mass flow rate of the liquid $\left(\mathrm{Q}_{\mathrm{L}}\right.$ in $\left.\mathrm{kg} \mathrm{s}^{-1}\right)$ and the associated thermal energy $\left(\mathrm{Q}_{\mathrm{H}}\right.$ in $\left.\mathrm{MW}\right)$ can be computed, rearranging the original relation of [5] as:

$$
\begin{gathered}
\mathrm{Q}_{\mathrm{L}}=\mathrm{Q}_{\mathrm{CO} 2} /\left(\mathrm{m}_{\mathrm{CO} 2} \times 0.044\right) \\
\mathrm{Q}_{\mathrm{H}}=10^{-3} \times \mathrm{Q}_{\mathrm{L}} \times \mathrm{H}_{\mathrm{L}}
\end{gathered}
$$

where $\mathrm{H}_{\mathrm{L}}\left(\right.$ in $\mathrm{kJ} \mathrm{kg}^{-1}$ ) is the original enthalpy of the liquid, $\mathrm{m}_{\mathrm{CO} 2}\left(\right.$ in $\mathrm{mol} \mathrm{kg}^{-1}$ ) is the original $\mathrm{CO}_{2}$ concentration, and 0.044 is the factor to convert moles to $\mathrm{kg}$. During the boiling of the upflowing liquid, the original energy is divided into a fraction associated with the residual liquid, which is possibly discharged by thermal springs or returned into 
the system with the descending columns of convective cells $\left(\mathrm{Q}_{\mathrm{res}}\right.$ and $\mathrm{Q}_{\mathrm{H} \text {,res }}$ in Figure 1), and a fraction transported toward the surface by the separated vapor. This ascending vapordominated phase condenses near the surface heating the soil, whereas the low-soluble $\mathrm{CO}_{2}$ is emitted in the atmosphere.

According to this model, geothermal areas often host sites characterized by emissions of hydrothermal $\mathrm{CO}_{2}$ from hot soils (steaming ground), which extend over their fumarolic fields. To measure the heat flow from these hot soils, several techniques have been developed since the 1950s [18] (and references therein). In these pioneer works, the heat flow is calculated by measuring soil temperatures at fixed depths and using empirical relations derived from long, time-consuming heat flow measurements with suitable calorimeters. For example, Fridriksson et al. [10] following [18], proposed that $q_{s}=5.2 \times 10^{-6} \times t_{15}{ }^{4}$, where $q_{s}$ is the heat flow (in $\mathrm{W} \mathrm{m}^{-2}$ ) and $t_{15}$ is the soil temperature (in ${ }^{\circ} \mathrm{C}$ ) at a depth of $15 \mathrm{~cm}$. However, this method is not generally valid because the empirically derived relation depends on local conditions, such as soil thermal conductivity and ambient temperature.

More recently Chiodini et al. [6,19] proposed an approach based on the measurement of the diffuse emission of hydrothermal $\mathrm{CO}_{2}$ from hot soils. In this approach the equivalent amount of steam that condenses in the subsurface $\left(Q_{\text {cond }}\right.$ in $\left.\mathrm{kg} \mathrm{s}^{-1}\right)$ and the associated heat release $\left(\mathrm{Q}_{\mathrm{H}, \text { cond }}\right.$ in $\left.\mathrm{MW}\right)$ is computed using the following equations:

$$
\begin{gathered}
\mathrm{Q}_{\text {cond }}=\mathrm{Q}_{\mathrm{CO} 2} \times \mathrm{R}_{\mathrm{H} 2 \mathrm{O} / \mathrm{CO} 2} \\
\mathrm{Q}_{\mathrm{H} \text {, cond }}=10^{-3} \times \mathrm{Q}_{\text {cond }} \times\left(\mathrm{H}_{\mathrm{V} \text {, Tcond }}-\mathrm{H}_{\mathrm{L}, \mathrm{Tamb}}\right)
\end{gathered}
$$

where $\mathrm{R}_{\mathrm{H} 2 \mathrm{O} / \mathrm{CO} 2}$ is the $\mathrm{H}_{2} \mathrm{O} / \mathrm{CO}_{2}$ weight ratio of the original (precondensation) vapor phase, and $\mathrm{H}_{\mathrm{V}}$, Tcond and $\mathrm{H}_{\mathrm{L}}$, Tamb are the enthalpies of the steam at the condensation temperature (2676 kJ kg ${ }^{-1}$ for a condensation temperature of $100{ }^{\circ} \mathrm{C}$; [20]) and of the liquid at the ambient temperature $\left(83.9 \mathrm{~kJ} \mathrm{~kg}^{-1}\right.$ for an ambient temperature of $20^{\circ} \mathrm{C}$; [20]), respectively. These equations are solved assuming a $\mathrm{R}_{\mathrm{H} 2 \mathrm{O} / \mathrm{CO} 2}$ equal to that of the fumaroles located in the zone degassing $\mathrm{CO}_{2}$ [6].

In the next sections we present and discuss the results obtained in different hydrothermal areas where $Q_{\mathrm{CO} 2}$ is used for the estimation of $\mathrm{Q}_{\mathrm{H} \text {,cond }}$ and $\mathrm{Q}_{\mathrm{H}}$.

\subsection{Thermal Energy Release from Soils Heated by Steam Condensation $\left(Q_{H, c o n d}\right)$}

The approach based on the application of Equations (3) and (4) is strongly supported by the spatial correspondence between hot soils and $\mathrm{CO}_{2}$ emissions, which frequently characterize the hydrothermal areas of active volcanoes and geothermal sites. Figure 2 shows, e.g., the map of $\mathrm{CO}_{2}$ fluxes and soil temperature (at $10 \mathrm{~cm}$ of depth) of the Solfatara di Pozzuoli (Campi Flegrei caldera, Italy), where this approach was first tested in 1998 [19]. These maps, as well as those reported in the following figures, were elaborated using the sequential Gaussian simulations (sGs; [21]) method. Equations (3) and (4) were solved with the measured $Q_{\mathrm{CO} 2}\left(17.6 \mathrm{~kg} \mathrm{~s}^{-1}\right)$ and $\mathrm{R}_{\mathrm{H} 2 \mathrm{O} / \mathrm{CO} 2}(2.2)$ obtaining the energy released by steam condensation from the Solfatara di Pozzuoli $\left(\mathrm{Q}_{\mathrm{H}, \mathrm{cond}} \sim 100 \mathrm{MW},[19]\right)$. This thermal energy was released from an area of $\sim 0.5 \mathrm{~km}^{2}$ (Table 1) and constituted the main part of the total energetic budget of the Campi Flegrei caldera. In fact, it was much higher than (i) the conductive heat flux over the $\sim 100 \mathrm{~km}^{2}$ of the entire caldera, (ii) the energy of the earthquakes, and (iii) the energy associated with ground deformation [19]. Subsequently, this method was applied to many geothermal sites in the world. Some examples and their relative references are reported in Table 1, where the acronym DDS (Diffuse Degassing Structure) indicates the areas diffusively emitting the hydrothermal, deeply derived $\mathrm{CO}_{2}$. The cases reported in Table 1 were selected based on the availability of (i) detailed $\mathrm{CO}_{2}$ flux surveys, (ii) estimation of the deeply derived emission (note that in the literature often is reported the total emission but not that related to the deep source), and (iii) the composition of the fumaroles located in the area. 


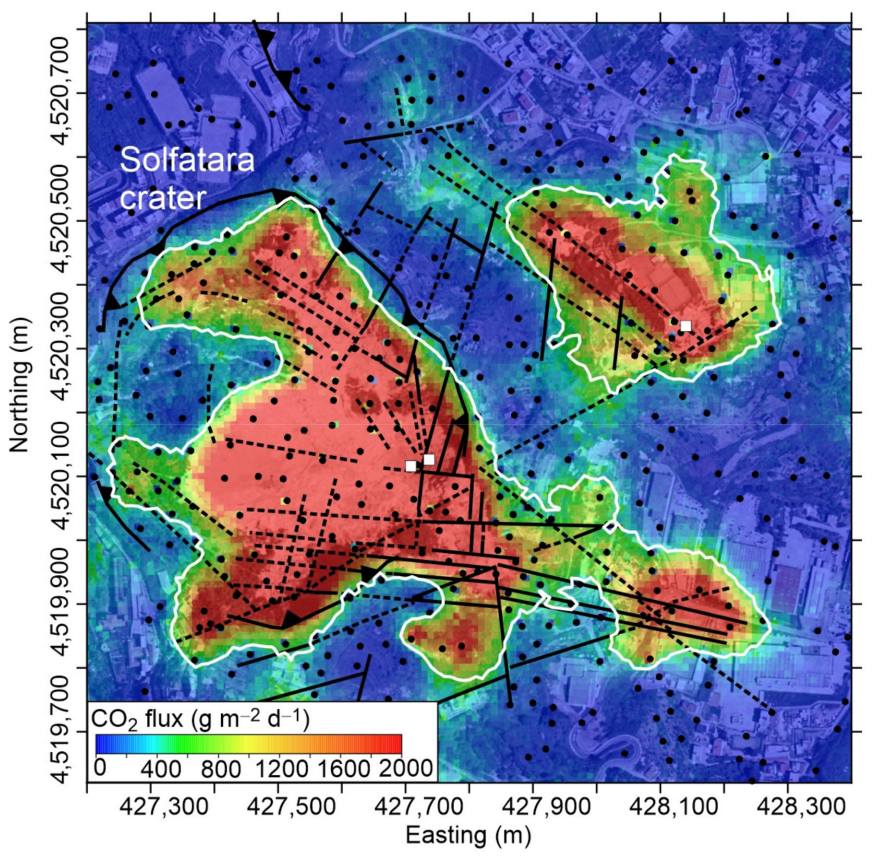

(a)

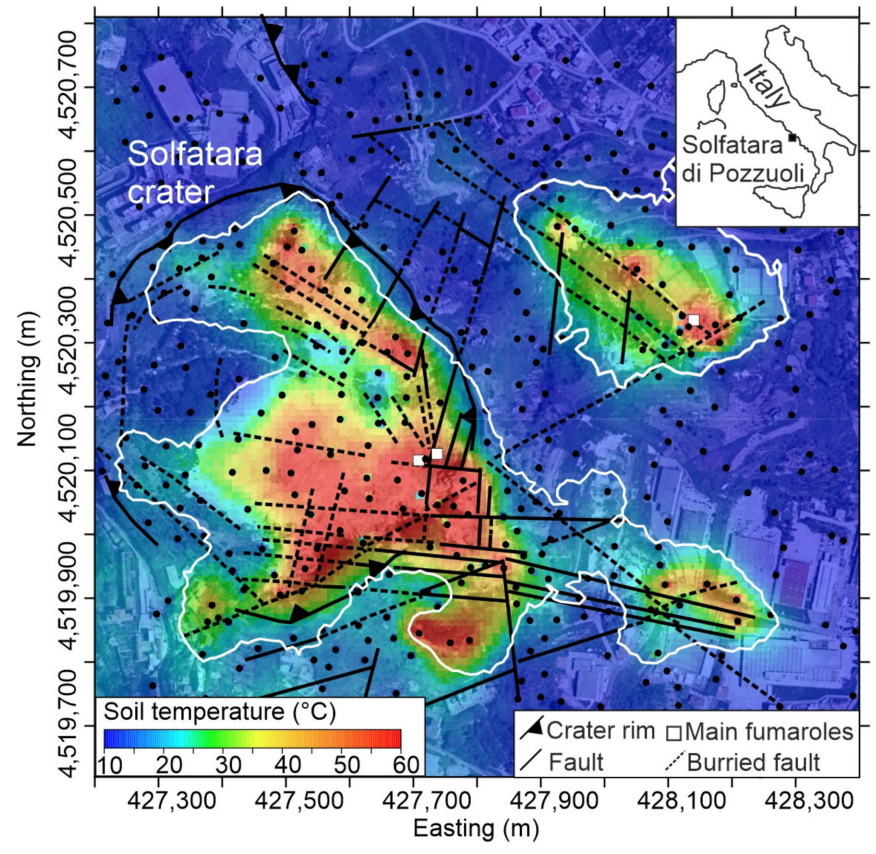

(b)

Figure 2. (a) $\mathrm{CO}_{2}$ flux; (b) soil temperature maps of the Solfatara di Pozzuoli in December 1998. The two maps were realised using 200 sGs. In the figure are reported the measurement points (dots) where both $\mathrm{CO}_{2}$ flux and soil temperature were measured and the contour of Solfatara DDS (white line). The DDS has been defined as the area where over $50 \%$ of the 200 simulated $\mathrm{CO}_{2}$ fluxes are higher than $50 \mathrm{~g} \mathrm{~m}^{-2} \mathrm{~d}^{-1}$, which is assumed as a reasonable maximum value for $\mathrm{CO}_{2}$ production by biological activity in the soil (see [22]). $\mathrm{CO}_{2}$ flux and soil temperature data from [22]). Coordinates refer to ED 50/UTM zone $33 \mathrm{~N}$. 
Table 1. Thermal energy associated with the $\mathrm{CO}_{2}$ degassing from hot soils from some geothermal/hydrothermal systems and relevant parameters for its calculation.

\begin{tabular}{|c|c|c|c|c|c|c|c|}
\hline Volcano (DDS) & Date & $\begin{array}{l}\text { DDS Extent } \\
{ }^{\mathbf{a}} \mathbf{k m}^{2}\end{array}$ & $\mathbf{R}_{\mathrm{H} 2 \mathrm{O} / \mathrm{CO} 2}$ & $\begin{array}{c}\mathrm{Q}_{\mathrm{CO} 2} \\
\mathrm{~kg} \mathrm{~s}^{-1}\end{array}$ & $\begin{array}{c}Q_{\text {cond }} \\
\mathrm{kg} \mathrm{s}^{-1}\end{array}$ & $\begin{array}{c}\mathrm{Q}_{\mathrm{H}, \text { cond }} \\
\mathrm{MW}\end{array}$ & Reference \\
\hline Campi Flegrei, Solfatara & $12 / 1998$ & $0.454^{\mathrm{b}}$ & 2.20 & 17.6 & 38.72 & 100.4 & [19] \\
\hline Campi Flegrei, Solfatara & $07 / 2000$ & $0.455^{b}$ & 2.27 & 17.13 & 38.88 & 100.8 & [6] \\
\hline Ischia, Donna Rachele & $04 / 2001$ & 0.058 & 147 & 0.11 & 15.48 & 40.1 & [6] \\
\hline Vesuvio, cone & $04 / 2000$ & 0.331 & 3.66 & 1.75 & 6.40 & 16.6 & [6] \\
\hline Vulcano, crater & $07 / 1998$ & 0.415 & 4.42 & 1.83 & 8.08 & 21.0 & [6] \\
\hline Vulcano, PL Beach & $03 / 2002$ & 0.018 & 5.24 & 0.22 & 1.15 & 3.0 & [6] \\
\hline Pantelleria, Favara Grande & $07 / 2004$ & 0.058 & 17.2 & 0.08 & 1.39 & 3.6 & [6] \\
\hline Masaya, Comalito & $03 / 2003$ & 0.010 & 1.60 & 0.22 & 0.35 & 0.9 & [6] \\
\hline Yellowstone, Mud volcanoes & $08 / 2003$ & 0.400 & 3.49 & 3.36 & 11.82 & 30.6 & [6] \\
\hline Yellowstone (HSB) & - & 0.160 & 15.63 & 0.80 & 12.48 & 32.3 & [23] \\
\hline Yellowstone (HLGB) & - & 0.040 & 250 & 0.02 & 5.79 & 15.0 & [23] \\
\hline Yellowstone $(\mathrm{CH})$ & $08 / 2014$ & $<0.035^{c}$ & 13.44 & 0.97 & 13.1 & 33.9 & [24] \\
\hline Nisyros-Stefanos & $10 / 2018$ & 0.086 & 36.0 & 0.19 & 7.00 & 18.1 & [25] \\
\hline Nisyros-Kaminakia & $10 / 2018$ & 0.164 & 6.90 & 0.16 & 1.08 & 2.8 & [25] \\
\hline Nisyros-Polibote & $10 / 2018$ & 0.031 & 26.0 & 0.07 & 1.68 & 4.4 & [25] \\
\hline Nisyros-Phlegeton & $10 / 2018$ & 0.053 & 21.2 & 0.04 & 0.85 & 2.2 & [25] \\
\hline Nisyros Lofos & $10 / 2018$ & 0.196 & 27.3 & 0.23 & 6.31 & 16.4 & [25] \\
\hline Nisyros-Ramos & $10 / 2018$ & 0.048 & 16.5 & 0.12 & 2.01 & 5.2 & [25] \\
\hline Nisyros-NEfault & $10 / 2018$ & 0.124 & 6.9 & 0.10 & 0.66 & 1.7 & [25] \\
\hline Nisyros-SENWline & $10 / 2018$ & 0.123 & 27.3 & 0.05 & 1.30 & 3.4 & [25] \\
\hline Nisyros-NESWline & $10 / 2018$ & 0.029 & 27.3 & 0.02 & 0.59 & 1.5 & [25] \\
\hline Nisyros, all DDSs & $10 / 2018$ & 0.825 & $6.9-36$ & 1.06 & 23.40 & 60.7 & [25] \\
\hline Nisyros, all DDSs & $02 / 2000$ & 0.690 & $6.1-36$ & 0.79 & 16.44 & 42.6 & [26] \\
\hline Copahue-Las Máquinas & $03 / 2014$ & $<0.321^{c}$ & 15.8 & 0.43 & 6.73 & 14.9 & [27] \\
\hline Copahue-Las Maquinitas I+II & $03 / 2014$ & $<0.079^{c}$ & 17.3 & 0.19 & 3.30 & 7.3 & [27] \\
\hline Termas Copahue & $03 / 2014$ & $<0.576^{c}$ & 16.6 & 1.05 & 17.45 & 38.7 & [27] \\
\hline Terceira-Furnas do Enxofre & $08 / 2014$ & $<0.024^{c}$ & 14.9 & 0.03 & 0.44 & 1.1 & [28] \\
\hline Teide & $07 / 2016$ & $<0.560^{c}$ & 2.24 & 2.44 & 5.47 & 14.2 & [29] \\
\hline Peteroa & $01 / 2020$ & $<0.08^{\mathrm{c}}$ & 12.9 & 0.08 & 0.77 & 2.6 & [30] \\
\hline
\end{tabular}

${ }^{a}$ For the criteria used to define the DDS extent see the original works; ${ }^{b}$ DDS extent from [22]; ${ }^{c}$ survey areas are reported when DDS extent is not defined in the original works.

\subsection{Thermal Energy of Convective Geothermal Liquid $\left(Q_{H}\right)$}

In Table 2 we report some results of the method for the estimation of the total thermal energy $Q_{H}$ involved in the convective generation of gas emissions (Figure 1) using published $[10,12,25]$ and unpublished data. Equations (1) and (2) were solved assuming $\mathrm{H}_{\mathrm{L}}$ and $\mathrm{m}_{\mathrm{CO} 2}$ of the hottest geothermal well as representative of the original convecting liquid. The computations completed at Latera caldera and Torre Alfina starting from the $\mathrm{CO}_{2}$ emission measurements are then described in detail in the following sections. Latera and Torre Alfina are two geothermal systems located in the Quaternary volcanic region of central Italy [31] (and references therein) which emit a low-temperature and dry gas phase, dominated by $\mathrm{CO}_{2}$. We use published measurements of the diffuse $\mathrm{CO}_{2}$ emission at Latera [12], while, in the case of Torre Alfina we use unpublished data.

Table 2. Thermal energy associated with the convection of geothermal fluids. The cases were selected based on the availability of $\mathrm{T}_{\mathrm{L}}$ and $\mathrm{m}_{\mathrm{CO} 2}$ of the original geothermal liquid.

\begin{tabular}{ccccccc}
\hline Name & $\begin{array}{c}\mathbf{Q}_{\mathbf{C O} 2} \\
\mathbf{k g ~ s}^{-\mathbf{1}}\end{array}$ & $\begin{array}{c}\mathbf{m}_{\mathrm{CO} 2} \\
\mathbf{m o l ~ k g ~}^{-\mathbf{1}}\end{array}$ & $\begin{array}{c}\mathbf{T}_{\mathbf{L}} \\
{ }^{\circ} \mathbf{C}\end{array}$ & $\begin{array}{c}\mathbf{H}_{\mathbf{L}} \\
\mathbf{k J ~ k g}^{-\mathbf{1}}\end{array}$ & $\begin{array}{c}\mathbf{Q}_{\mathbf{L}} \\
\mathbf{k g ~ s}^{-\mathbf{1}}\end{array}$ & $\begin{array}{c}\mathbf{Q}_{\mathbf{H}} \\
\mathbf{M W}\end{array}$ \\
\hline Reykjanes $^{1}$ & 0.156 & 0.0284 & 290 & 1289 & 125 & 161 \\
Nisyros $^{2}$ & 1.060 & 0.29 & 340 & 1594 & 83.9 & 134 \\
Torre Alfina $_{\text {Latera }}^{1.064}$ & 4.050 & 0.33 & 150 & 632.2 & 73.3 & 126.1 \\
\hline
\end{tabular}




\subsection{1. $\mathrm{CO}_{2}$ Emission and Convective Heat Release from the Latera Caldera}

Results of a detailed investigation of the $\mathrm{CO}_{2}$ degassing from the Latera caldera [12] are here synthesized and discussed. The Latera geothermal system is hosted in permeable Mesozoic carbonates covered by impermeable flysch layers and volcanic products (see [12] for a detailed geological setting). Surface manifestations of the active fluid circulation consist of $\mathrm{CO}_{2}$-rich shallow groundwaters, areas of strong soil diffuse $\mathrm{CO}_{2}$ emission, and low-temperature (from $19^{\circ} \mathrm{C}$ to $31^{\circ} \mathrm{C}$ ) $\mathrm{CO}_{2}$-rich gas vents. The $\mathrm{CO}_{2}$ emission was quantified and mapped through 930 flux measurements performed with the accumulation chamber over an area of $\sim 10.8 \mathrm{~km}^{2}$ (Figure 3; [12]). The $\mathrm{CO}_{2}$ flux map shows a NE-SW band of high $\mathrm{CO}_{2}$ emission (Latera DDS), corresponding to the structural high hosting the geothermal reservoir $[12,32,33]$. Notably, the productive wells of Latera (L3/3D, L2 and L4 in Figure 3) are located in this anomalous band.

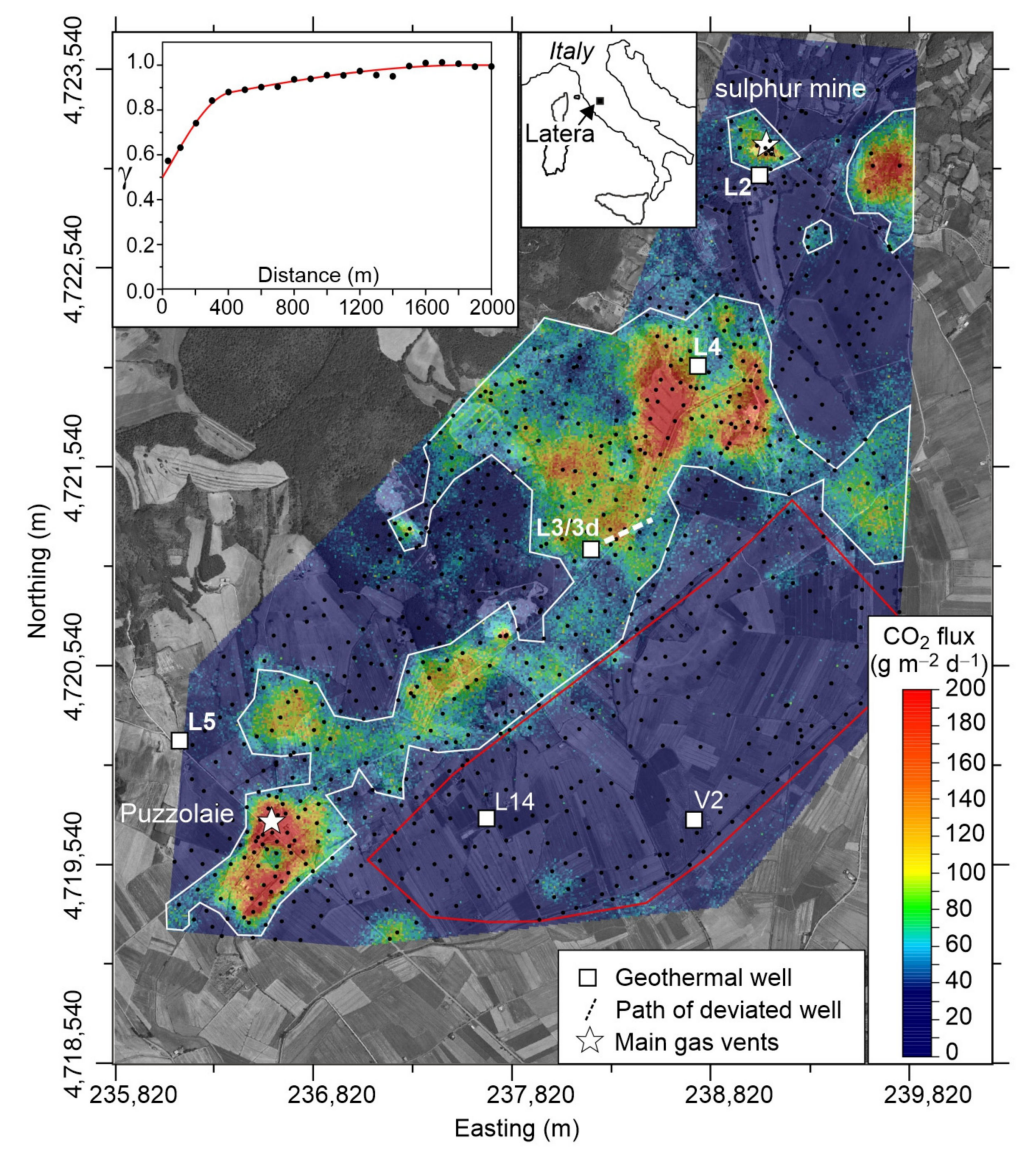

Figure 3. Map of the $\mathrm{CO}_{2}$ diffuse degassing from Latera obtained through $100 \mathrm{sGs}$ simulations (modified after [12]). In the figure are reported the measurement points (dots); the experimental variogram and the variogram model (red curve) used in the sGs (upper left inset); the contour of the Latera DDS (white line) defined as the area where over $50 \%$ of the 100 simulated $\mathrm{CO}_{2}$ flux values are higher than the biogenic $\mathrm{CO}_{2}$ flux threshold $\left(50 \mathrm{~g} \mathrm{~m}^{-2} \mathrm{~d}^{-1}\right.$ [12]); the contour of the area used to define the biogenic $\mathrm{CO}_{2}$ background flux (red line); and the location of the main vents and geothermal wells. Coordinates refer to WGS 84/UTM zone $33 \mathrm{~N}$.

The total $\mathrm{CO}_{2}$ emission computed from the map resulted in $497 \mathrm{t} \mathrm{d}^{-1}$, including both the geothermal and biogenic flux contributions. The mean soil biogenic production, which was characterized using a subset of measurements performed in an area far from the main degassing zones (red contour in Figure 3), resulted in $15.7 \mathrm{~g} \mathrm{~m}^{-2} \mathrm{~d}^{-1}$. Removing the biogenic $\mathrm{CO}_{2}$ contribution, the deep $\mathrm{CO}_{2}$ emission from Latera resulted in $328 \mathrm{td}^{-1}$ [12]. Then, integrating this large-scale survey with the results of a detailed $\mathrm{CO}_{2}$ flux campaign 
focused on the biggest gas manifestation in Latera, that is the Puzzolaie area, these authors concluded that the total deep $\mathrm{CO}_{2}$ emission accounted for $\sim 350 \mathrm{t} \mathrm{d}^{-1}\left(4.05 \mathrm{~kg} \mathrm{~s}^{-1}\right)$.

The total thermal energy involved in the convective upflow and boiling of the geothermal liquids was calculated with Equations (1) and (2), using the published T- $\mathrm{m}_{\mathrm{CO} 2}$ data of the hottest geothermal liquid (Latera $3 \mathrm{D}$ well, $\mathrm{T}=238^{\circ} \mathrm{C}, \mathrm{m}_{\mathrm{CO} 2}=0.73 \mathrm{~mol} \mathrm{~kg}^{-1}$; [34,35]). The geothermal fluid upflow rate $\left(\mathrm{Q}_{\mathrm{L}}\right)$, feeding the $\mathrm{CO}_{2}$ emission of $4.05 \mathrm{~kg} \mathrm{~s}^{-1}$, resulted in $126 \mathrm{~kg} \mathrm{~s}^{-1}$ and the correspondent thermal energy $\left(\mathrm{Q}_{\mathrm{H}}\right)$ in $130 \mathrm{MW}$.

\subsection{2. $\mathrm{CO}_{2}$ Emission and Convective Heat Release from Torre Alfina, Italy}

The Torre Alfina system consists of both a geothermal liquid water reservoir with temperatures between 125 and $150{ }^{\circ} \mathrm{C}$ and an overlying gas-cap, mainly $\mathrm{CO}_{2}$, at a pressure of about 40 bars [36], located at $\sim 400 \mathrm{~m}$ of depth. Similarly to Latera, the reservoir is hosted in a structural high of the Mesozoic carbonate formations overlaid by flysch impermeable layers and by quaternary volcanic products [36,37]. The area above the geothermal system is characterized by high $\mathrm{pCO}_{2}$ groundwaters circulating in the volcanic products [38], $\mathrm{CO}_{2}$-rich gas vents, and areas with visible soil $\mathrm{CO}_{2}$ emissions. Soil $\mathrm{CO}_{2}$ diffuse degassing was investigated with the accumulation chamber method [15] in 2009-2010. This survey consisted of (i) $917 \mathrm{CO}_{2}$ flux measurements performed in the main $\mathrm{CO}_{2}$ emission area located southward of the Torre Alfina village (named "Le Solfonare" by [39]; Figure 4), (ii) 119 measurements in a peripheral area with slightly high flux values (named "small degassing area"), and (iii) 262 measurements of low $\mathrm{CO}_{2}$ flux randomly distributed in a larger area and specifically performed to quantify the background soil $\mathrm{CO}_{2}$ emissions (Table S1, Supplementary Material).

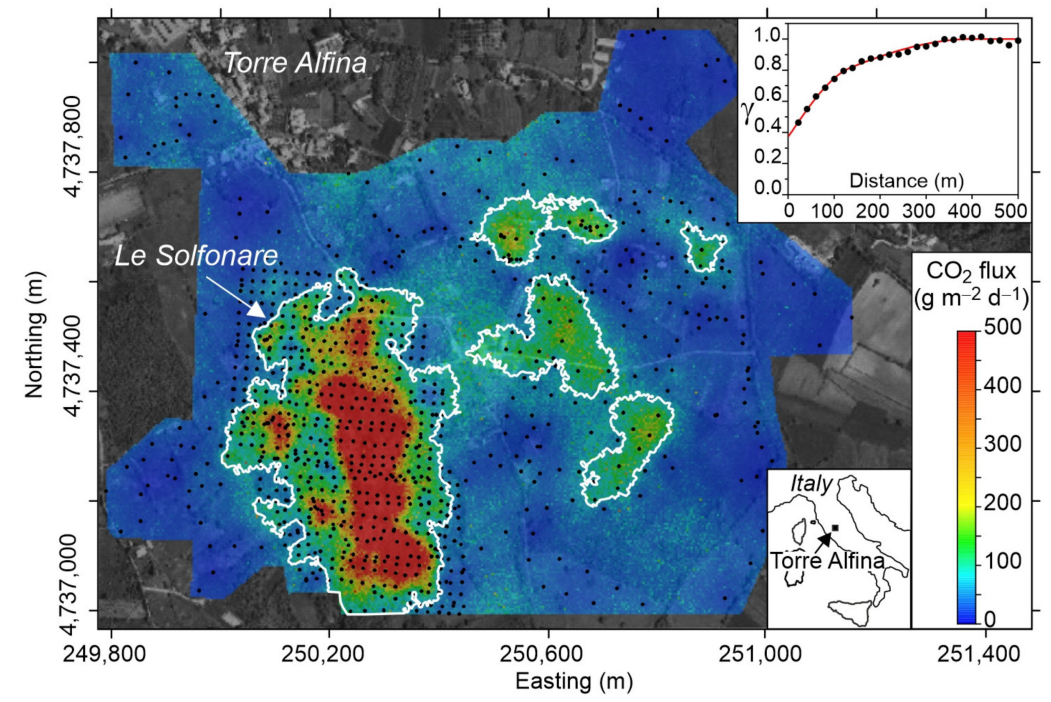

Figure 4. Map of the $\mathrm{CO}_{2}$ diffuse degassing from Torre Alfina obtained through 200 sGs simulations. In the figure are reported the measurement points (dots); the experimental variogram and the variogram model (red curve) used in the sGs (upper right inset); and the contour of the Torre Alfina DDS (white line) defined as the area where over $50 \%$ of the 200 simulated $\mathrm{CO}_{2}$ flux values are higher than the biogenic $\mathrm{CO}_{2}$ flux threshold $\left(35 \mathrm{~g} \mathrm{~m}^{-2} \mathrm{~d}^{-1}\right.$, see the text). Coordinates refer to WGS 84/UTM zone $33 \mathrm{~N}$.

The $\mathrm{CO}_{2}$ flux map of Le Solfonare, constructed with the sGs method [21], highlights a main NNW-SSE degassing structure and weaker anomalies located eastward (Figure 4). In total, these two anomalous zones emit $104.7 \mathrm{t} \mathrm{d}^{-1}$ of $\mathrm{CO}_{2}$, which become $107.0 \mathrm{t} \mathrm{d}^{-1}$ summing the $2.3 \mathrm{t} \mathrm{d}^{-1}$ released by the small degassing area. This value includes both the geothermal $\mathrm{CO}_{2}$ and the background emission due to the biologic activity in the soil. To separate these two contributions, we applied the GSA (Graphic Statistic Approach described in [15] and in [21]), which is based on the Sinclair's partitioning method of 
lognormal polymodal distribution of data [40]. The $\mathrm{CO}_{2}$ flux measurements are reported in the log-probability plot of Figure 5 (grey points), where, for comparison, are also reported the 262 background values as a separated data set (blue points). The distribution of the $\mathrm{CO}_{2}$ fluxes is explainable by the overlapping of the background population (defined only with the blue points) and two other lognormal populations of higher fluxes, representing the deep $\mathrm{CO}_{2}$ contribution (Table 3). Based on the statistical parameters of the Population 1, we estimate an average background $\mathrm{CO}_{2}$ emission of $14.2 \mathrm{~g} \mathrm{~m}^{-2} \mathrm{~d}^{-1}$ which, interestingly, is very similar to the $\mathrm{CO}_{2}$ background flux of Latera, closely located to Torre Alfina and characterized by a similar type of vegetation and use of soil. Considering this background $\mathrm{CO}_{2}$ emission we estimate the total deep $\mathrm{CO}_{2}$ emission at $91.9 \mathrm{t} \mathrm{d}^{-1}\left(1.06 \mathrm{~kg} \mathrm{~s}^{-1}\right)$. We assume that $35 \mathrm{~g} \mathrm{~m}^{-2} \mathrm{~d}^{-1}$ (95th percentile of Population 1) reflects the threshold value above which the gas emission is totally geogenic-derived. This value is used to delimitate the structures degassing deeply derived $\mathrm{CO}_{2}$ (Torre Alfina DDS, white contour in Figure 4).

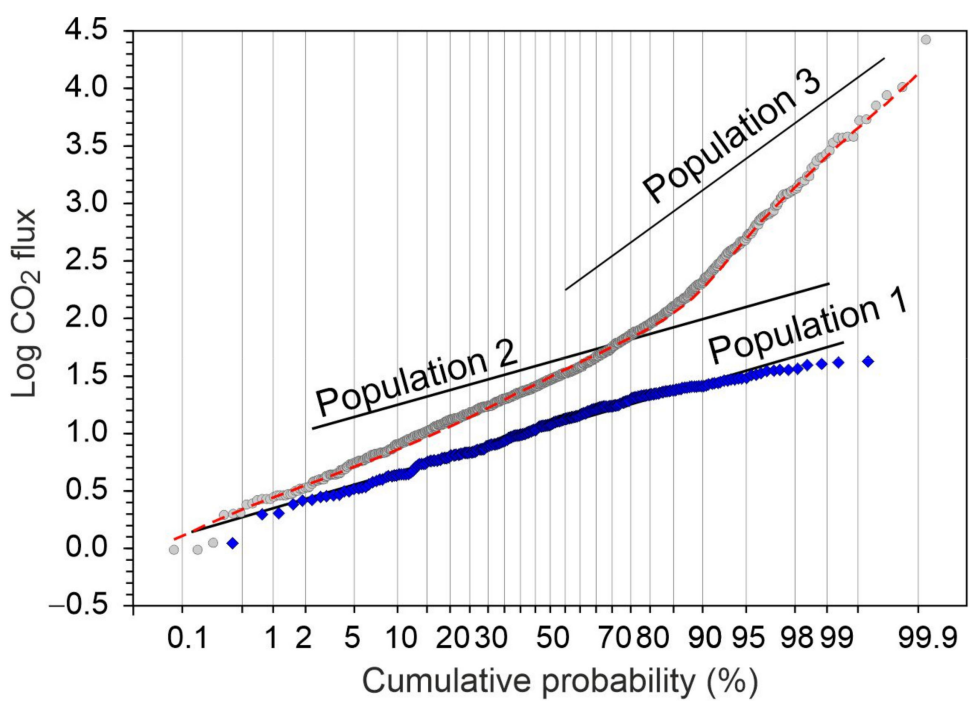

Figure 5. Probability plot of $\log \mathrm{CO}_{2}$ fluxes. The entire dataset is reported with grey points while the background $\mathrm{CO}_{2}$ fluxes are reported as blue symbols. The black lines represent the partitioned populations while the dashed red curve represents their mixture in the proportion reported in Table 3.

Table 3. Statistical parameters of the individual partitioned populations.

\begin{tabular}{ccccc}
\hline Population & Mean Log $\mathrm{CO}_{\mathbf{2}}$ Flux & $\boldsymbol{\sigma}$ & $\boldsymbol{\%}$ & $\begin{array}{c}\mathrm{Mean} \mathrm{CO}_{\mathbf{2}} \text { Flux * } \\
\mathbf{g ~ m}^{-\mathbf{2}} \mathbf{d}^{-\mathbf{1}}\end{array}$ \\
\hline 1 & 1.05 & 0.30 & 33 & $14.2(13.3-15.2)$ \\
2 & 1.62 & 0.29 & 46 & $52.1(49.4-54.8)$ \\
3 & 2.15 & 0.75 & 21 & $626(441-905)$ \\
\hline
\end{tabular}

* The mean of the $\mathrm{CO}_{2}$ flux was then estimated using a Monte Carlo simulation procedure. Between brackets are reported the 5th and 95th percentile of the mean $\mathrm{CO}_{2}$ flux values returned by the Monte Carlo simulation procedure [41].

The thermal energy involved in the upflow of the geothermal liquid of the Torre Alfina system was computed with Equations (1) and (2), considering temperature and $\mathrm{m}_{\mathrm{CO} 2}$ data of the wells reported in [34]. Among these data we selected the maximum temperature $\left(150{ }^{\circ} \mathrm{C}\right)$ at which corresponds a $\mathrm{m}_{\mathrm{CO} 2}$ equal to $0.33 \mathrm{~mol} \mathrm{~kg}^{-1}$. Considering the $\mathrm{CO}_{2}$ diffuse emission of $1.06 \mathrm{~kg} \mathrm{~s}^{-1}$, we estimated a geothermal fluid upflow $\left(\mathrm{Q}_{\mathrm{L}}\right)$ equal to $73.2 \mathrm{~kg} \mathrm{~s}^{-1}$ and an associated thermal energy $\left(\mathrm{Q}_{\mathrm{H}}\right)$ equal to $46 \mathrm{MW}$.

\section{Enthalpy and $\mathrm{CO}_{2}$ Mass Balances of Regional Aquifers}

In the previous section we combined surface measurements of the $\mathrm{CO}_{2}$ flux with the enthalpy and $\mathrm{CO}_{2}$ content of deep liquids to calculate the heat release and the thermal energy of the geothermal fluids exsolving $\mathrm{CO}_{2}$. When the upflowing fluids dissolve in 
aquifers, we do not need any direct information about the deep fluids to estimate the heat flux and the amount of injected $\mathrm{CO}_{2}$, as they can be calculated through the carbon mass and enthalpy balances of groundwaters.

This approach was used in central Italy [17] where the comparison of the $\mathrm{CO}_{2}$ flux map [42] with the conductive heat flux map [43] points out that the area of anomalous $\mathrm{CO}_{2}$ degassing extends eastward beyond the thermal anomaly (Figure 6). The heat flux shows in fact a sharp decrease from values higher than $100 \mathrm{~mW} \mathrm{~m}^{-2}$, typical of the Tyrrhenian side, to values lower than $50 \mathrm{~mW} \mathrm{~m}^{-2}$ in the area of the regional aquifers of the Apennine chain. Here, the large amounts of infiltrating waters that circulate in the permeable carbonate formations possibly cools the crust and causes the low conductive heat flux measured in the area $[17,44]$.

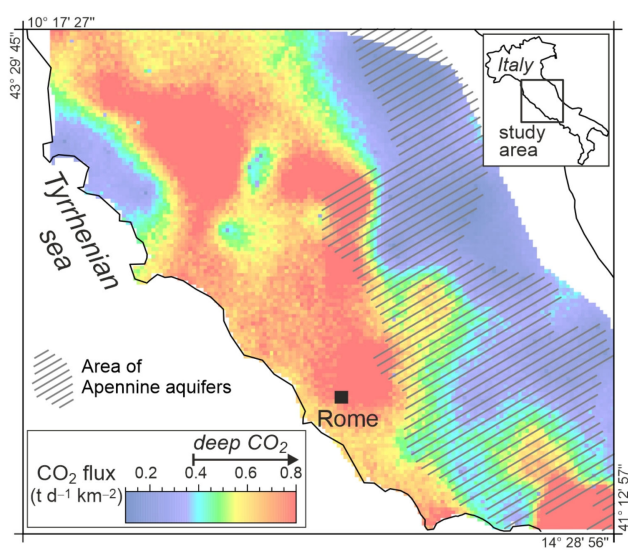

(a)

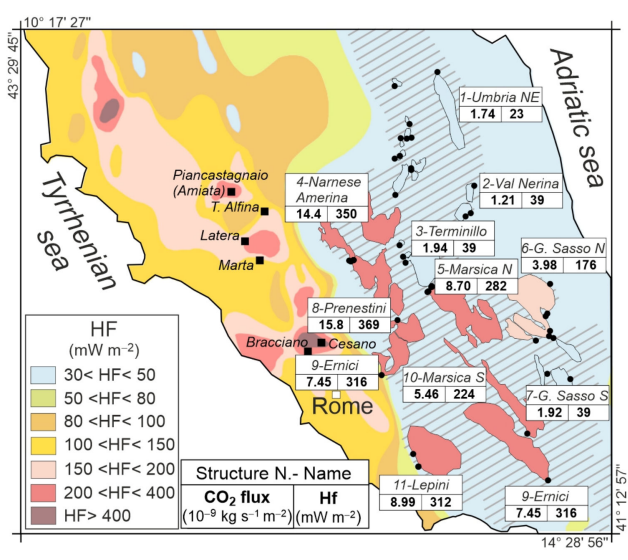

(b)

Figure 6. (a) $\mathrm{CO}_{2}$ flux map of central Italy (modified from [17]); (b) Conductive heat flux map of central Italy ([43] modified from [17]). The location of the investigated aquifers and springs are reported together with the mean of the $\mathrm{CO}_{2}$ flux and of the geothermal heat flux computed for each aquifer. Locations of the Latera and the Torre Alfina geothermal systems and of other geothermal wells are also shown. The area of Apennine aquifers is highlighted in both maps (dashed area).

To investigate the heat transfer in this area, Chiodini et al. [17] applied carbon mass and enthalpy balances to 46 springs of high-flow rate located in 11 large carbonate aquifers (Figure $6 \mathrm{~b}$ ). The carbon mass balance of the springs allowed [17] to differentiate the components contributing to the total dissolved inorganic carbon (TDIC), i.e., the carbon deriving from carbonate minerals dissolution $\left(\mathrm{C}_{\mathrm{carb}}\right)$ and that from sources external to the aquifers $\left(\mathrm{C}_{\text {ext }}\right)$.

The diagram of $\delta^{13} C_{\text {ext }}$ vs. $C_{\text {ext }}$ (Figure 7) highlights two groups of waters: one characterized by low $\mathrm{C}_{\text {ext }}$ (mean $\left.=2.3 \mathrm{mmol} \mathrm{L}{ }^{-1}\right)$ and light carbon isotope compositions $\left(\delta^{13} \mathrm{C}_{\mathrm{ext}}\right.$ from $-10 \%$ to $-25 \%$; blue points), the other by higher $\mathrm{C}_{\text {ext }}$ (mean $\left.=12.7 \mathrm{mmol} \mathrm{L}^{-1}\right)$ and heavier carbon isotope compositions $\left(\delta^{13} \mathrm{C}_{\text {ext }}\right.$ from $-10 \%$ to $-5 \%$; magenta points). The first group reflects normal groundwaters with $\mathrm{C}_{\mathrm{ext}}$ deriving from a mixture of atmospheric $\mathrm{CO}_{2}$ and carbon produced by biogenic sources present in the soil of the recharge areas. The second group forms by the addition of an isotopically heavier carbon $\left(\delta^{13} \mathrm{C} \sim-1.5 \%\right.$ \% source to normal groundwaters. This heavier carbon source is ascribed to the deeply derived $\mathrm{CO}_{2}$ typically emitted from this region, where the numerous and large natural gas emissions of central Italy show a mean $8^{13} \mathrm{C}$ value of about $-1.5 \%$ [45]. The mass flow rate of $\mathrm{C}_{\mathrm{ext}}\left(\mathrm{Q}_{\mathrm{CO} 2}\right.$ in $\left.\mathrm{kg} \mathrm{s}^{-1}\right)$ in each aquifer is computed by multiplying its concentration by the discharge rate of the structure and the $\mathrm{CO}_{2}$ flux by dividing $\mathrm{Q}_{\mathrm{CO} 2}$ by the surface area of the aquifer. 
Table 4. Main hydrogeological parameters of the aquifers (total flow rate $\mathrm{Q}$ and surface area of the hydrogeological basin $\mathrm{A}$ ) and results of the carbon mass and enthalpy balances ( $\mathrm{Hf}, \mathrm{Q}_{\mathrm{H}}, \mathrm{CO}_{2}$ flux, $\mathrm{Q}_{\mathrm{CO} 2}$ ). Data are from [17].

\begin{tabular}{|c|c|c|c|c|c|c|c|}
\hline N. & Name & $\begin{array}{c}Q \\
\mathrm{~m}^{3} \mathrm{~s}^{-1}\end{array}$ & $\underset{\mathbf{k m}^{2}}{\mathrm{~A}}$ & $\begin{array}{c}\text { Hf } \\
\mathrm{mW} \mathrm{m} \mathrm{m}^{-2}\end{array}$ & $\begin{array}{c}\mathrm{Q}_{\mathbf{H}} \\
\mathbf{M W}\end{array}$ & $\begin{array}{c}\mathrm{CO}_{2} \text { Flux } \\
\mathrm{kg} \mathrm{s}^{-1} \mathrm{~m}^{-2}\end{array}$ & $\begin{array}{c}\mathrm{Q}_{\mathrm{CO} 2} \\
\mathrm{~kg} \mathrm{~s}^{-1}\end{array}$ \\
\hline 1 & Umbria NE & 6.73 & 399 & 23 & 9.3 & $1.74 \times 10^{9}$ & 0.69 \\
\hline 2 & Val Nerina & 1.78 & 105 & 39 & 4.1 & $1.21 \times 10^{9}$ & 0.13 \\
\hline 3 & Terminillo & 5.79 & 340 & 39 & 13.2 & $1.94 \times 10^{9}$ & 0.66 \\
\hline 4 & Narnese-Amerina & 15.00 & 740 & 350 & 259.4 & $1.44 \times 10^{8}$ & 10.67 \\
\hline 5 & Marsica N & 22.35 & 716 & 282 & 202.2 & $8.70 \times 10^{9}$ & 6.23 \\
\hline 6 & G Sasso N & 17.95 & 793 & 176 & 139.9 & $3.98 \times 10^{9}$ & 3.16 \\
\hline 7 & G Sasso S & 7.00 & 309 & 39 & 12.2 & $1.92 \times 10^{9}$ & 0.59 \\
\hline 8 & Prenestini & 9.00 & 499 & 369 & 184.3 & $1.58 \times 10^{8}$ & 7.87 \\
\hline 9 & Ernici & 18.00 & 618 & 316 & 195.5 & $7.45 \times 10^{9}$ & 4.60 \\
\hline 10 & Marsica S & 9.80 & 411 & 224 & 91.9 & $5.46 \times 10^{9}$ & 2.24 \\
\hline 11 & Lepini & 14.80 & 525 & 312 & 163.7 & $8.99 \times 10^{9}$ & 4.72 \\
\hline
\end{tabular}

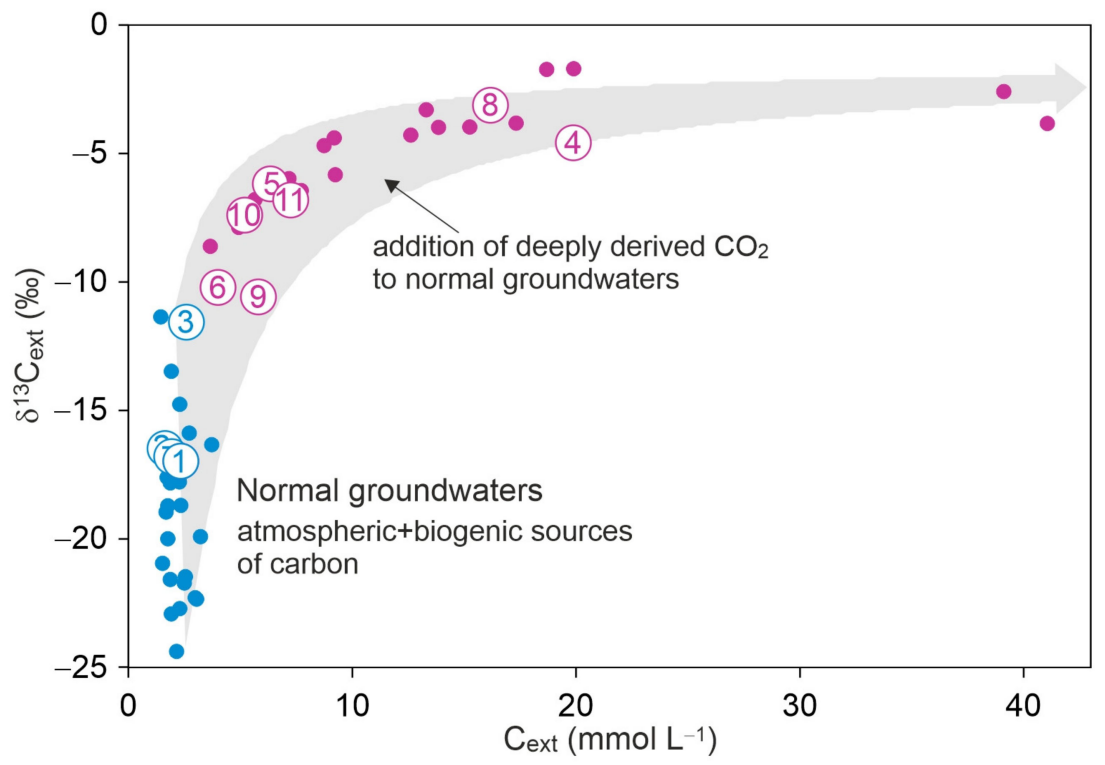

Figure 7. ${ }^{13} \delta \mathrm{C}_{\text {ext }}$ vs. $\mathrm{C}_{\text {ext }}$ diagram (modified from [17]). The diagram shows the presence of two groups of water: the normal groundwater where the carbon derives from the atmospheric and biogenic $\mathrm{CO}_{2}$ (blue points) and waters generated by the addition of deeply derived $\mathrm{CO}_{2}$ to normal groundwaters (magenta point). In the figure are also reported the mean $C_{\text {ext }}$ and $\delta^{13} C_{\text {ext }}$ of the eleven investigated aquifers (open circles, numbers refer to Table 4). The grey band corresponds to the theoretical compositions computed by adding deep $\mathrm{CO}_{2}$ with a $\delta^{13} \mathrm{C}=-1.5 \%$ o to the normal groundwaters (redrawn from [17]).

The enthalpy balance was performed using the method of [46], based on the temperature difference between the recharge water and the water discharged from the spring $(\Delta \mathrm{T})$. This is expressible as:

$$
\Delta \mathrm{T}=\mathrm{T}_{\mathrm{s}}-\mathrm{T}_{\mathrm{r}}=(\mathrm{Hf} \times \mathrm{A}) /\left(\rho_{\mathrm{w}} \times \mathrm{C}_{\mathrm{w}} \times \mathrm{q}\right)+\Delta \mathrm{z} \times\left(\mathrm{g} / \mathrm{C}_{\mathrm{W}}\right)
$$

where $T_{s}$ and $T_{r}$ are the temperatures of discharge (springs) and recharge water, respectively, Hf is the geothermal heat flux $\left(\mathrm{W} \mathrm{m}^{-2}\right), \rho \mathrm{w}\left(\mathrm{kg} \mathrm{m}^{-3}\right)$ and $\mathrm{C}_{\mathrm{W}}\left(\mathrm{J} \mathrm{kg}^{-1} \mathrm{~K}^{-1}\right)$ are the density and the heat capacity of the liquid water, $q$ is the spring volumetric flow rate $\left(\mathrm{m}^{3} \mathrm{~s}^{-1}\right), \mathrm{A}$ is the surface area $\left(\mathrm{m}^{2}\right)$ of the hydrogeological basin of the spring, $\Delta \mathrm{z}(\mathrm{m})$ is the difference between the average elevation of the recharge area and the elevation of the spring, and $g$ is the gravitational acceleration $\left(\mathrm{m} \mathrm{s}^{-2}\right.$ ) (see [17] for further details on the computation of the different parameters). 
The results of both carbon mass and enthalpy balances for each aquifer are synthesized in Table 4. The total heat flow rate from each aquifer $\left(\mathrm{Q}_{\mathrm{H}}\right)$ was computed by multiplying the mean heat flux Hf by the surface area of the aquifer. The mean values of the $\mathrm{CO}_{2}$ fluxes and Hf of the aquifers are also reported in the map of Figure 6b. This map shows that the aquifers located in the northern and eastern sector of the study area are characterized by both low $\mathrm{CO}_{2}$ fluxes and low $\mathrm{Hf}$, close to values reported for the same area by the conductive heat flux map of Italy (Figure 6b). Conversely, all the other aquifers have much higher Hf values (from 180 to $370 \mathrm{~mW} \mathrm{~m}^{-2}$ ) up to one order of magnitude higher than the conductive heat flux. These high Hf values are observed on the Tyrrhenian side and gently decrease moving eastward. Practically, the thermal anomaly characterizing the Tyrrhenian sector of central Italy is considerably wider and extends toward the east including a large portion of the central Apennine, similarly to the deeply derived $\mathrm{CO}_{2}$ emission (Figure 6a).

\section{$\mathrm{CO}_{2}$ and Heat Flows in Central Italy}

The heat flow $\left(\mathrm{Q}_{\mathrm{H}}\right)$ computed for the 11 hydrogeological structures is plotted against the $\mathrm{CO}_{2}$ mass flow rate $\left(\mathrm{Q}_{\mathrm{CO}}\right)$ in Figure 8 where, for comparison, are also reported relevant data relative to the geothermal systems of central Italy and of other zones of the Earth.

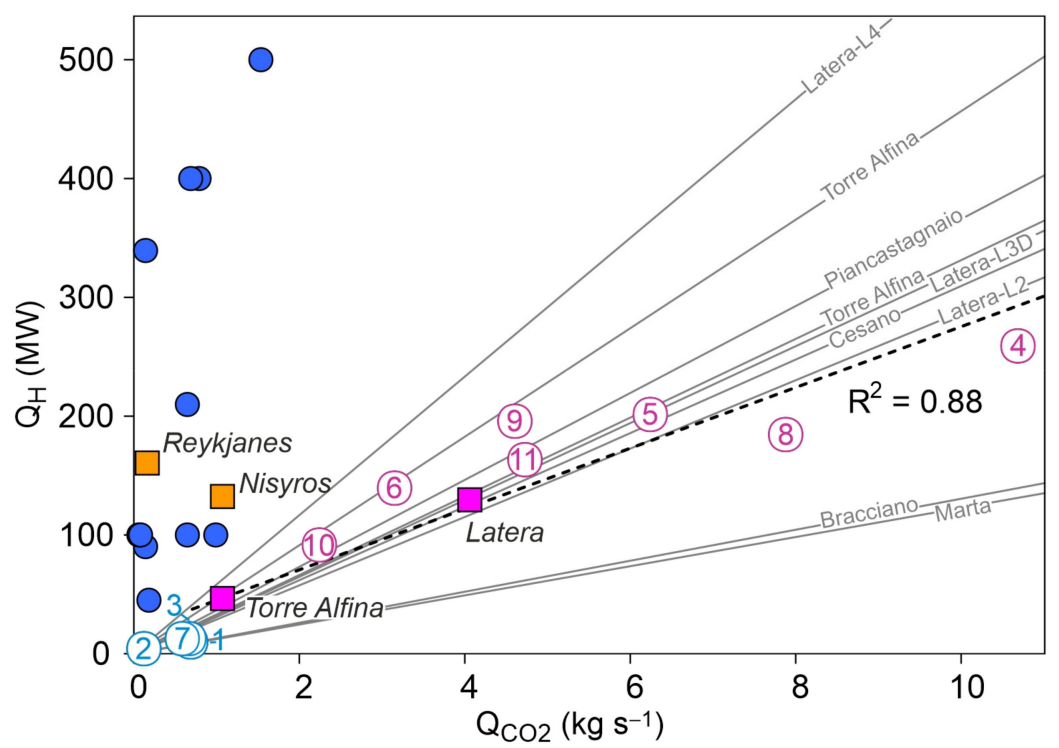

Figure 8. $\mathrm{CO}_{2}$ mass flow rates $\left(\mathrm{Q}_{\mathrm{CO} 2}\right)$ plotted against heat flows $\left(\mathrm{Q}_{\mathrm{H}}\right)$. In the figure are reported: the results of the carbon mass and enthalpy balance of the 11 aquifers of Central Italy (open circle; numbers as in Table 4, colours as in Figure 7); the values computed for diffuse degassing areas (magenta and orange squares, see Table 2); the values of the geothermal systems of Taupo (New Zealand) and Salton Trough (USA) (from [5]; blue dots); and the $\mathrm{Q}_{\mathrm{CO} 2} / \mathrm{Q}_{\mathrm{H}}$ ratios of central Italy geothermal systems derived from deep wells data (from [34]; grey lines; see Figure 6 for the locations of the wells). The best fit of the aquifers, Torre Alfina and Latera diffuse degassing data is also shown (dashed black line).

It is worth noting that all the measured or derived data from central Italy point to a source characterized by a similar and high $\mathrm{CO}_{2}$ / heat ratio, which is about $0.03 \mathrm{~kg}$ of $\mathrm{CO}_{2}$ per $\mathrm{MJ}$ of geothermal heat. Specifically, the studied aquifers affected by the input of the deep $\mathrm{CO}_{2}$ have a mean $\mathrm{CO}_{2}$ / heat ratio of $0.033 \mathrm{~kg} \mathrm{MJ}{ }^{-1}$, the two diffuse $\mathrm{CO}_{2}$ degassing areas of Torre Alfina and Latera of 0.02 and $0.03 \mathrm{~kg} \mathrm{MJ}^{-1}$, respectively, and the geothermal wells of $0.037 \mathrm{~kg} \mathrm{MJ}^{-1}$. These similar ratios possibly indicate the existence of a unique original fluid feeding the geothermal systems of central Italy and generating the $\mathrm{CO}_{2}$ and geothermal heat anomalies that characterize the entire Tyrrhenian sector of the region. The similar $\mathrm{CO}_{2}$ / heat ratio and the large extent of the $\mathrm{CO}_{2}$ and geothermal heat flux anomalies (thousands of square kilometres) point to a deep source, i.e., the Tyrrhenian mantle wedge 
that in the region is located at depths of between 20 and $25 \mathrm{~km}$ [47-49]. The Tyrrhenian mantle, which is rich in fluids produced by the underlying subducted Adria slab, was in fact already recognized as the main source of the $\mathrm{CO}_{2}$ emission of the area [42,50-53]. The $\mathrm{CO}_{2}$ / heat ratios measured in central Italy $\left(\sim 0.03 \mathrm{~kg} \mathrm{MJ}^{-1}\right)$ would possibly reflect the composition of the fluids emitted from a mantle anomalously enriched in $\mathrm{CO}_{2}$. Notably, the $\mathrm{CO}_{2}$ / heat ratios measured or derived for the geothermal system in central Italy are very high with respect to other geothermal systems of the world. For example, they are one order of magnitude higher than those of the Taupo and Salton Trough geothermal systems, where the computations of [5] indicate a mean $\mathrm{CO}_{2} /$ heat ratio of $0.003 \mathrm{~kg} \mathrm{MJ}^{-1}$.

\section{Discussion and Conclusions}

The heat flux of a region is a central parameter in geothermal prospecting and it is normally measured through expensive deep drillings. This classical method allows the estimation of the conductive heat flux but not of the convective-advective heat transported by the fluids. In this study, we reviewed the methods based on the measurement of the $\mathrm{CO}_{2}$ emission for the computation of the convective-advective geothermal heat flow, both at a local (hydrothermal sites, few $\mathrm{km}^{2}$ ) and regional scale $\left(100-1000 \mathrm{~km}^{2}\right.$ ).

At the local scale, we first discussed the case of the Campi Flegrei caldera. Here, the $\mathrm{CO}_{2}$-based method clearly shows that the advective heat associated with the hot soils diffusively emitting $\mathrm{CO}_{2}$ at Solfatara di Pozzuoli, is by far the main term of the energetic budget of the entire caldera. Subsequently, we focused on the cases of Latera and Torre Alfina where the depressurization of the geothermal liquid, particularly rich in $\mathrm{CO}_{2}$, causes the separation of a gas phase rich in incondensable gases, which are emitted in the atmosphere by low-temperature manifestations. For these latter cases, the measured $\mathrm{CO}_{2}$ emission, together with the temperature and the $\mathrm{CO}_{2}$ concentration in the geothermal deep fluid, allowed us to compute the thermal energy associated with the original convecting geothermal liquid, which resulted in dozens to hundreds of MW (Table 2). These remarkably high values can be considered as minimum estimates of the energy potentially exploitable from a given hydrothermal system because, assuming that the natural process occurs at a steady state condition, the emitted energy equals the energy entering the system. Therefore, the measurement of the $\mathrm{CO}_{2}$ emission from hydrothermal sites is a valuable tool for geothermal prospection.

At the regional scale, we reported the case of eleven large aquifers (each of hundreds $\mathrm{km}^{2}$ ) located in the central Apennine. Here, $\mathrm{CO}_{2}$ and heat fluxes have been derived from carbon mass and enthalpy balances of the groundwaters by combining hydrogeological and hydrogeochemical data. Notably, the thermal anomaly of the Tyrrhenian side of Italy extends eastward in the Apennine area, where the conductive heat flow is very low. Furthermore, the ratios between the deeply derived $\mathrm{CO}_{2}$ and the heat entering the studied aquifers $\left(\mathrm{CO}_{2} /\right.$ heat $\left.\sim 0.03 \mathrm{~kg} \mathrm{MJ}^{-1}\right)$ are very similar to each other and comparable to those measured in the nearby geothermal fields of Tuscany and Latium (Figure 8). This finding suggests a common $\mathrm{CO}_{2}$-rich fluid source in central Italy, which is ascribed to the Tyrrhenian mantle. The typical $\mathrm{CO}_{2} /$ heat ratio of central Italy is in fact one order of magnitude higher than that of other geothermal zones of the Earth (e.g., Taupo and Salton Trough geothermal systems).

This comparison introduces a further aspect linked to the study of the $\mathrm{CO}_{2}$ degassing from geothermal regions, and that is the environmental impact of carbon dioxide and other greenhouse gases (GHG) associated with geothermal power production. In most cases, the emissions of GHG are much lower than those associated with fossil fuel $[8,54,55]$, making geothermal utilization for power production a technology with an extremely low carbon footprint. However, in central Italy and in other regions such as Turkey [56-58], geothermal power plants can release significant quantities of GHG into the atmosphere. Since the ratio of $\mathrm{CO}_{2}$ emissions from power plants to natural emissions is a measure of the environmental impact associated with geothermal power production [8,59], it is very important to evaluate the natural $\mathrm{CO}_{2}$ degassing rate before and during the exploitation of 
the geothermal resource. Besides the potentiality in the exploration phase, the measure of the $\mathrm{CO}_{2}$ emissions can thus find valuable applications in evaluating the environmental impact of geothermal exploitation.

Supplementary Materials: The following are available online at https:/ /www.mdpi.com/article/10 $.3390 /$ en14206590/s1, Table S1: Measured diffuse $\mathrm{CO}_{2}$ fluxes at Torre Alfina (Italy).

Author Contributions: Conceptualization, G.C.; investigation-field work, G.C., C.C., F.F., G.B. and B.L.; writing-original draft preparation, G.C., C.C., G.B. and F.F.; writing-review and editing, G.B., C.C., G.C., F.F., S.C. and L.R. All authors have read and agreed to the published version of the manuscript.

Funding: This research and the APC was funded by MIUR, grant number project no. PRIN20172017LMNLAW "Connect4Carbon".

Institutional Review Board Statement: Not applicable.

Informed Consent Statement: Not applicable.

Data Availability Statement: The original data presented in this study are available in the Supplementary Material, Table S1.

Conflicts of Interest: The authors declare no conflict of interest. The funders had no role in the design of the study; in the collection, analyses, or interpretation of data; in the writing of the manuscript, or in the decision to publish the results.

\section{References}

1. Barnes, I.; Irwin, P.W.; White, D.E. Global Distribution of Carbon Dioxide Discharges, and Major Zones of Seismicity; U.S. Geologcial Survey: Washington, DC, USA, 1978.

2. Irwin, W.P.; Barnes, I. Tectonic relations of carbon dioxide discharges and earthquakes. J. Geophys. Res. 1980, 85, 3115-3121. [CrossRef]

3. Tamburello, G.; Pondrelli, S.; Chiodini, G.; Rouwet, D. Global-scale control of extensional tectonics on $\mathrm{CO}_{2}$ earth degassing. Nat. Commun. 2018, 9, 4608. [CrossRef]

4. Hayba, D.O.; Ingebritsen, S.E. Multiphase groundwater flow near cooling plutons. J. Geophys. Res. 1997, 102, 12235-12252. [CrossRef]

5. Kerrick, D.M.; McKibben, M.A.; Seward, T.M.; Caldeira, K. Convective hydrothermal $\mathrm{CO}_{2}$ emission from high heat-flow regions. Chem. Geol. 1995, 121, 285-293. [CrossRef]

6. Chiodini, G.; Granieri, D.; Avino, R.; Caliro, S.; Costa, A.; Werner, C. Carbon dioxide diffuse degassing and estimation of heat release from volcanic and hydrothermal systems. J. Geophys. Res. 2005, 110, B08204. [CrossRef]

7. Werner, C.; Cardellini, C. Comparison of carbon dioxide emissions with fluid upflow, chemistry, and geologic structures at the Rotorua geothermal system, New Zealand. Geothermics 2006, 35, 221-238. [CrossRef]

8. Armannsson, H.; Fridriksson, T.; Kristjansson, B.R. $\mathrm{CO}_{2}$ emissions from geothermal power plants and natural geothermal activity in Iceland. Geothermics 2005, 34, 286-296. [CrossRef]

9. Shen, L.C.; Wu, K.Y.; Xiao, Q.; Yuan, D.X. Carbon dioxide degassing flux from two geothermal fields in Tibet, China. Chin. Sci. Bull. 2011, 56, 3783-3793. [CrossRef]

10. Fridriksson, T.; Kristjansson, B.R.; Armannsson, H.; Margretardottir, E.; Olafsdottir, S.; Chiodini, G. $\mathrm{CO}_{2}$ emissions and heat flow through soil, fumaroles, and steam heated mud pools at the Reykjanes geothermal area, SW Iceland. Appl. Geochem. 2006, 21, 1551-1569. [CrossRef]

11. Rogie, J.D.; Kerrick, D.M.; Chiodini, G.; Frondini, F. Flux measurements of nonvolcanic $\mathrm{CO}_{2}$ emission from some vents in central Italy. J. Geophys. Res. 2000, 105, 8435-8445. [CrossRef]

12. Chiodini, G.; Baldini, A.; Barberi, F.; Carapezza, M.L.; Cardellini, C.; Frondini, F.; Granieri, D.; Ranaldi, M. Carbon dioxide degassing at Latera caldera (Italy): Evidence of geothermal reservoir and evaluation of its potential energy. J. Geophys. Res. 2007, 112, B12204. [CrossRef]

13. Chiodini, G.; Frondini, F; Cardellini, C.; Parello, F.; Peruzzi, L. Rate of diffuse carbon dioxide Earth degassing estimated from carbon balance of regional aquifers: The case of central Apennine, Italy. J. Geophys. Res. 2000, 105, 8423-8434. [CrossRef]

14. Chiodini, G.; Frondini, F.; Kerrick, D.M.; Rogie, J.; Parello, F.; Peruzzi, L.; Zanzari, A.R. Quantification of deep $\mathrm{CO}_{2}$ fluxes from Central Italy. Examples of carbon balance for regional aquifers and of soil diffuse degassing. Chem. Geol. 1999, 159, $205-222$. [CrossRef]

15. Chiodini, G.; Cioni, R.; Guidi, M.; Raco, B.; Marini, L. Soil $\mathrm{CO}_{2}$ flux measurements in volcanic and geothermal areas. Appl. Geochem. 1998, 13, 543-552. [CrossRef] 
16. Werner, C.; Wyngaard, J.C.; Brantley, S.L. Eddy-correlation measurement of hydrothermal gases. Geophys. Res. Lett. 2000, 27, 2925-2928. [CrossRef]

17. Chiodini, G.; Cardellini, C.; Caliro, S.; Chiarabba, C.; Frondini, F. Advective heat transport associated with regional Earth degassing in central Apennine (Italy). Earth Planet. Sci. Lett. 2013, 373, 65-74. [CrossRef]

18. Dawson, G.B. The nature and assessment of heat flow from hydrothermal areas. N. Z. J. Geol. Geophys. 1964, 7, 155-171. [CrossRef]

19. Chiodini, G.; Frondini, F.; Cardellini, C.; Granieri, D.; Marini, L.; Ventura, G. $\mathrm{CO}_{2}$ degassing and energy release at Solfatara volcano, Campi Flegrei, Italy. J. Geophys. Res. 2001, 106, 16213-16221. [CrossRef]

20. Keenan, J.H.; Keyes, F.G.; Hill, P.G.; Moore, J.G. Steam Tables: Thermodynamic Properties of Water Including Vapor, Liquid, and Solid Phases; John Wiley \& Sons: Hoboken, NJ, USA, 1969; p. 162.

21. Cardellini, C.; Chiodini, G.; Frondini, F. Application of stochastic simulation to $\mathrm{CO}_{2}$ flux from soil: Mapping and quantification of gas release. J. Geophys. Res. 2003, 108, 2425. [CrossRef]

22. Cardellini, C.; Chiodini, G.; Frondini, F.; Avino, R.; Bagnato, E.; Caliro, S.; Lelli, M.; Rosiello, A. Monitoring diffuse volcanic degassing during volcanic unrests: The case of Campi Flegrei (Italy). Sci. Rep. 2017, 7, 6757. [CrossRef]

23. Harvey, M.C.; Rowland, J.V.; Chiodini, G.; Rissmann, C.F.; Bloomberg, S.; Hernandez, P.A.; Mazot, A.; Viveiros, F.; Werner, C. Heat flux from magmatic hydrothermal systems related to availability of fluid recharge. J. Volcanol. Geotherm. Res. 2015, 302, 225-236. [CrossRef]

24. Lin, P.; Deering, C.D.; Werner, C.; Torres, C. Origin and quantification of diffuse $\mathrm{CO}_{2}$ and $\mathrm{H}_{2} \mathrm{~S}$ emissions at Crater Hills, Yellowstone National Park. J. Volcanol. Geotherm. Res. 2019, 377, 117-130. [CrossRef]

25. Bini, G.; Chiodini, G.; Cardellini, C.; Vougioukalakis, G.E.; Bachmann, O. Diffuse emission of $\mathrm{CO}_{2}$ and convective heat release at Nisyros caldera (Greece). J. Volcanol. Geotherm. Res. 2019, 376, 44-53. [CrossRef]

26. Caliro, S.; Chiodini, G.; Galluzzo, D.; Granieri, D.; La Rocca, M.; Saccorotti, G.; Ventura, G. Recent activity of Nisyros volcano (Greece) inferred from structural, geochemical and seismological data. Bull. Volcanol. 2005, 67, 358-369. [CrossRef]

27. Chiodini, G.; Cardellini, C.; Lamberti, M.C.; Agusto, M.; Caselli, A.; Liccioli, C.; Tamburello, G.; Tassi, F.; Vaselli, O.; Caliro, S. Carbon dioxide diffuse emission and thermal energy release from hydrothermal systems at Copahue-Caviahue Volcanic Complex (Argentina). J. Volcanol. Geotherm. Res. 2015, 304, 294-303. [CrossRef]

28. Viveiros, F.; Chiodini, G.; Cardellini, C.; Caliro, S.; Zanon, V.; Silva, C.; Rizzo, A.L.; Hipolito, A.; Moreno, L. Deep CO 2 emitted at Furnas do Enxofre geothermal area (Terceira Island, Azores archipelago). An approach for determining $\mathrm{CO}_{2}$ sources and total emissions using carbon isotopic data. J. Volcanol. Geotherm. Res. 2020, 401, 106968. [CrossRef]

29. Alonso, M.; Padrón, E.; Sumino, H.; Hernández, P.A.; Melián, G.V.; Asensio-Ramos, M.; Rodríguez, F.; Padilla, G.; García-Merino, M.; Amonte, C.; et al. Heat and Helium-3 Fluxes from Teide Volcano, Canary Islands, Spain. Geofluids 2019, $2019,3983864$. [CrossRef]

30. Lamberti, M.C.; Agusto, M.; Llano, J.; Nogues, V.; Venturi, S.; Velez, M.L.; Albite, J.M.; Yiries, J.; Chiodini, G.; Cardellini, C.; et al. Soil $\mathrm{CO}_{2}$ flux baseline in Planchon-Peteroa Volcanic Complex, Southern Andes, Argentina-Chile. J. S. Am. Earth Sci. 2021, 105, 102930. [CrossRef]

31. Peccerillo, A. Roman comagmatic province (Central-Italy)—Evidence for subduction-related magma genesis. Geology 1985, 13, 103-106. [CrossRef]

32. Barberi, F.; Innocenti, F.; Landi, P.; Rossi, U.; Saitta, M.; Santacroce, R.; Villa, I.M. The evolution of latera caldera (central Italy) in the light of subsurface data. Bull. Volcanol. 1984, 47, 125-141. [CrossRef]

33. Bertrami, R.; Cameli, G.M.; Lovari, F.; Rossi, U. Discovery of Latera geothermal field: Problems of the exploration and research. In Proceedings of the International Congress on Geothermal Energy, Florence, Italy, 14-17 May 1984; pp. 1-18.

34. Gambardella, B.; Cardellini, C.; Chiodini, G.; Frondini, F.; Marini, L.; Ottonello, G.; Zuccolini, M.V. Fluxes of deep CO 2 in the volcanic areas of central-southern Italy. J. Volcanol. Geotherm. Res. 2004, 136, 31-52. [CrossRef]

35. Cioni, R.; Marini, L. The Reservoir Liquids. In A Thermodynamic Approach to Water Geothermometry; Springer International Publishing: Cham, Switzerland, 2020; pp. 31-137. [CrossRef]

36. Buonasorte, G.; Cataldi, R.; Ceccarelli, A.; Costantini, A.; D’Offizzi, S.; Lazzarotto, A.; Ridolfi, A.; Baldi, P.; Barelli, A.; Bertini, G.; et al. Ricerca ed esplorazione nell'area geotermica di Torre Alfina (Lazio Umbria). Boll. Soc. Geol. Ital. 1988, 107, $265-337$.

37. Barelli, A.; Celati, R.; Manetti, G. Gas-water interface rise during early exploitation tests in alfina geothermal field (Northern Latium, Italy). Geothermics 1977, 6, 199-208. [CrossRef]

38. Chiodini, G.; Frondini, F.; Ponziani, F. Deep structures and carbon-dioxide degassing in central Italy. Geothermics 1995, $24,81-94$. [CrossRef]

39. Carapezza, M.L.; Ranaldi, M.; Gattuso, A.; Pagliuca, N.M.; Tarchini, L. The sealing capacity of the cap rock above the Torre Alfina geothermal reservoir (Central Italy) revealed by soil $\mathrm{CO}_{2}$ flux investigations. J. Volcanol. Geotherm. Res. 2015, $291,25-34$. [CrossRef]

40. Sinclair, A.J. Selection of threshold values in geochemical data using probability graphs. J. Geochem. Explor. 1974, 3, 129-149. [CrossRef]

41. Chiodini, G.; Cardellini, C.; Caliro, S.; Avino, R.; Donnini, M.; Granieri, D.; Morgantini, N.; Sorrenti, D.; Frondini, F. The hydrothermal system of Bagni San Filippo (Italy): Fluids circulation and $\mathrm{CO}_{2}$ degassing. Ital. J. Geosci. 2020, 139, $383-397$. [CrossRef] 
42. Chiodini, G.; Cardellini, C.; Amato, A.; Boschi, E.; Caliro, S.; Frondini, F.; Ventura, G. Carbon dioxide Earth degassing and seismogenesis in central and southern Italy. Geophys. Res. Lett. 2004, 31, L07615. [CrossRef]

43. Cataldi, R.; Mongelli, F.; Squarci, P.; Taffi, L.; Zito, G.; Calore, C. Geothermal ranking of Italian territory. Geothermics 1995, 24, 115-129. [CrossRef]

44. Della Vedova, B.; Bellani, S.; Pellis, G.; Squarci, P. Deep temperatures and surface heat flow distribution. In Anatomy of an Orogen: The Apennines and Adjacent Mediterranean Basins; Vai, G.B., Martini, I.P., Eds.; Springer: Dordrecht, The Netherlands, 2001; pp. 65-76. [CrossRef]

45. Chiodini, G.; Caliro, S.; Cardellini, C.; Frondini, F.; Inguaggiato, S.; Matteucci, F. Geochemical evidence for and characterization of $\mathrm{CO}_{2}$ rich gas sources in the epicentral area of the Abruzzo 2009 earthquakes. Earth Planet. Sci. Lett. 2011, 304, 389-398. [CrossRef]

46. Manga, M.; Kirchner, J.W. Interpreting the temperature of water at cold springs and the importance of gravitational potential energy. Water Resour. Res. 2004, 40, W05110. [CrossRef]

47. Barchi, M.R.; Minelli, G.R.; Pialli, G. The CROP 03 profile: A synthesis of results on deep structures of the Northern apennines. Mem. Soc. Geol. Ital. 1998, 52, 383-400.

48. Ventura, G.; Cinti, F.R.; Di Luccio, F.; Pino, N.A. Mantle wedge dynamics versus crustal seismicity in the Apennines (Italy). Geochem. Geophys. Geosystems 2007, 8, Q02013. [CrossRef]

49. Doglioni, C. A proposal for the kinematic modelling of W-dipping subductions-Possible applications to the TyrrhenianApennines system. Terra Nova 1991, 3, 423-434. [CrossRef]

50. Minissale, A. Origin, transport and discharge of $\mathrm{CO}_{2}$ in central Italy. Earth Sci. Rev. 2004, 66, 89-141. [CrossRef]

51. Chiarabba, C.; Chiodini, G. Continental delamination and mantle dynamics drive topography, extension and fluid discharge in the Apennines. Geology 2013, 41, 715-718. [CrossRef]

52. Peccerillo, A.; Frezzotti, M.L. Magmatism, mantle evolution and geodynamics at the converging plate margins of Italy. J. Geol. Soc. 2015, 172, 407-427. [CrossRef]

53. Frezzotti, M.L.; Peccerillo, A.; Panza, G. Carbonate metasomatism and $\mathrm{CO}_{2}$ lithosphere-asthenosphere degassing beneath the Western Mediterranean: An integrated model arising from petrological and geophysical data. Chem. Geol. 2009, 262, 108-120. [CrossRef]

54. Bertani, R.; Thain, I. Geothermal power generating plant $\mathrm{CO}_{2}$ emission survey. IGA News 2002, 49, 1-3.

55. Bonafin, J.; Pietra, C.; Bonzanini, A.; Bombarda, P. $\mathrm{CO}_{2}$ emissions from geothermal power plants: Evaluation of technical solutions for $\mathrm{CO}_{2}$ reinjection. In Proceedings of the European Geothermal Congress, Den Haag, The Netherlands, 11-14 June 2019.

56. Haizlip, J.; Tut Haklidir, F.S. High noncondensible gas liquid dominated geothermal reservoir, Kizildere, Turkey. Geotherm. Resour. Counc. Trans. 2011, 35, 615-618.

57. Aksoy, N.; Solak Gok, O.; Mutlu, H.; Kılınc, G. $\mathrm{CO}_{2}$ Emission from Geothermal Power Plants in Turkey. In Proceedings of the World Geothermal Congress, Melbourne, Australia, 19-25 April 2015; pp. 1-7.

58. Fridriksson, T.; Mateos, A.; Audinet, P.; Orucu, Y. Greenhouse Gases from Geothermal Power Production; World Bank: Washington, DC, USA, 2016.

59. Lenzi, A.; Paci, M.; Giudetti, G.; Gambini, R. Tracing Ancient Carbon Dioxide Emission in the Larderello Area by Means of Historical Boric Acid Production Data. Energies 2021, 14, 4101. [CrossRef] 